\title{
Evaluation of antibacterial activity and molecular characterization of bacteria from Holothuria atra intestine collected from anthropogenic and non-anthropogenic region in Karimunjawa, Indonesia
}

\author{
BAMBANG SULARDIONO^, NINIEK WIDYORINI, DJOKO SUPRAPTO, DIAH AYUNINGRUM, \\ ARIF RAHMAN
}

${ }^{1}$ Department of Aquatic Resources, Faculty of Fisheries and Marine Sciences, Universitas Diponegoro. Jl. Prof. H. Soedarto, S.H., Tembalang, Semarang 50275, Central Java, Indonesia. Tel.: +62-24-7474698, Fax.: +62-24-7474698, `email: bambangsulardiono@ gmail.com

\author{
Manuscript received: 17 March 2020. Revision accepted: 18 June 2020.
}

\begin{abstract}
Sulardiono B, Widyorini N, Suprapto D, Ayuningrum D, Rahman A. 2020. Evaluation of antibacterial activity and molecular characterization of bacteria from Holothuria atra intestine collected from anthropogenic and non-anthropogenic region in Karimunjawa, Indonesia. Biodiversitas 21: 3149-3155. Evaluation of antibacterial activity and molecular characterization of bacteria from the intestine of Holothuria atra is needed in the anthropogenic region of Menjangan Besar, Karimunjawa. The research aims to evaluate antibacterial activity and molecular characterization of bacteria from intestine of Holothuria atra collected from anthropogenic and non-anthropogenic regions in Karimunjawa, Indonesia. Sea cucumber samples were collected at Menjangan Besar waters as anthropogenic region (code of HM) and Alang-alang waters as non-anthropogenics region (code of HA), Karimunjawa National Park, Indonesia. The $H$. atra sample collection was using purposive sampling method. Examination of the bacteria from isolation until molecular characterisation was done at the Tropical Marine Biotechnology Laboratory, Uiversitas Diponegoro. The isolation process was conducted using spread plate method, followed by bacterial isolates purification using streak plate method. Screening of antibacterial activity using the agar plug method, as well as molecular identification was conducted by 16S rDNA PCR amplification. The results of this study indicated that a total of 26 bacterial strains were successfully isolated from sea cucumber intestine, consisted of eleven bacterial isolates from $H$. atra in Menjangan Besar waters and the rest fifteen isolates from $H$. atra in Alang-alang waters. The preliminary assay of antibacterial test showed $\mathrm{H}$. atra in both waters have potential bacterial isolates. Those bacterial isolates with antibacterial activity were HM1.2 and HA1.1, which based on molecular identification, showed isolates HM1.2 and HA1.1 had the closest similarity with Bacillus paramcoides and Vibrio alginolyticus consecutively, with BLAST homology $98 \%$ and $99 \%$. The accession number for both isolates were LC550090 and LC550089, respectively.
\end{abstract}

Keywords: Antibacterial activity, Holothuria atra, Intestine, Karimunjawa

\section{INTRODUCTION}

Menjangan Besar waters are included in the Karimunjawa National Park area, where the waters are part of the tourism and cultivation zones (Sulisyati et al. 2018). Because there are a variety of activities that are anthropogenic, so they have an impact on the decline in the aquatic environment. Sulardiono et al. 2018 explained that the environmental status in the waters of Menjangan Besar is oligotrophic, where there is a tendency of low quality or towards eutrophication, so that it will affect the biological characteristics of the microbiological community. On the other hand, the Alang-alang waters is a rehabilitation zone. The area is imposed restrictions on activities, where the activities carried out may not cause damage to the ecosystem that is in these waters, with all its resources.

The presence of sea cucumber associated bacteria provides an opportunity to use these organisms as the main source of new bacteria and sources of bioactive compounds including antimicrobial compounds. In waters that have the potential to pollute the environment have an impact on the increase in the abundance of sedimentary bacteria, thus providing opportunities for entry into the digestive system of sea cucumbers during the feeding process as depositfeeding. Sea cucumbers obtain food by the ingestion of marine sediment, or by filtration of seawater. Depositfeeding holothurians are prominent members of many deep benthic communities. The association of bacteria with sea cucumbers plays an important role in various ways, including development, immunity, metabolism, and physiology (McFall-Ngai et al. 2013; Bordenstein and Theis 2015; Theis et al. 2016).

Sea cucumbers $H$. atra live in shallow coastal waters and are widely distributed in Karimunjawa, which has an important role in the food chain system in its environment. According to Dissanayake et al. 2012, H. atra has a preference for seagrass habitat, where much is dominated by organic matter, gravel, and substrate, whereas according to Hartati et al. 2019 there is a relationship between habitat and species physiology ecology. Sea cucumber H. atra has a fairly strong susceptibility from the influence of the quality of the surrounding environment, especially the effect of infection on the body of sea cucumbers. According to Liu, et al. 2011, bacteria as microbiota in the intestine are known to play an important role in the health status of aquatic animals, which can affect the function of 
aquatic animals, including biological activities for the development and maintenance of the immune system and defense against pathogens. The structure of intestinal microbiome or intestinal community is strongly influenced by eating or dietary habits. Sea cucumber eating deposits increase the abundance of bacteria and the rate of remineralization of organic matter in coastal sediments, thus providing a mechanism to increase the decomposition of organic matter (MacTavish, et al. 2012). Furthermore, intestinal microbiota is considered an integral component of the host, due to its important role in modulation of the immune system, proliferation of intestinal epithelium and regulation of food energy intake. Understanding these factors, studying the microbial community is very important for applications in these aquatic animals which still require basic investigations.

To date, the study of sea cucumber gut microbiota especially bacteria from the intestine part is still limited. The latest research by Pagán-Jiménez et al. 2019 reported that the gut microbiota in sea cucumber Holothuria glaberrima is dominated by bacteria from the phylum Proteobacteria. However, the role of this bacteria remains unclear. Thus, this research aims to isolate the bacteria from intestine of $H$. atra, to evaluate antibacterial activity and molecular characterization of bacteria from intestine of $H$. atra collected from anthropogenic and nonanthropogenic region in Karimunjawa, Indonesia. This potential and its bacterial symbiont characteristics can be used as a database in the management of sea cucumber resources in the waters of Menjangan Besar as a tourism and cultivation zone in Karimunjawa National Park.

\section{MATERIALS AND METHODS}

\section{Specimen collection}

Holothurians of the species $H$. atra were collected from Menjangan Besar waters as a tourism and cultivation zone (code of $\mathrm{HM}$ ) and Alang-alang waters as a rehabilitation zone (code of $\mathrm{HA}$ ), in the Karimunjawa National Park, Indonesia, with skin diving to a depth of around 2-3 m. The total of specimens collected was ten, consists of five specimens of $H$. atra from Menjangan Besar and the rest five specimen collected from Alangalang. During collection, sea cucumbers were put into sterile ziplock plastic bags and placed in a cool box until examined. Specimen of sea cucumber $H$. atra can be seen in Figure 1.A, while the position of taking bacteria in the intestines of sea cucumbers (Pagán-Jiménez et al. 2019), can be seen in Figure 1.B.

\section{Environment quality observation}

Observation of environment quality was conducted including physical and chemical properties; $\mathrm{pH}$, temperature, visibility, current, dissolved oxygen (DO), salinity, and organic material sediment. Those parameters were measured using the proper tools including $\mathrm{pH}$-meter, thermometer, Secchi disk, current ball, DO meter, refractometer, and organic material measurement in sediment test, respectively.

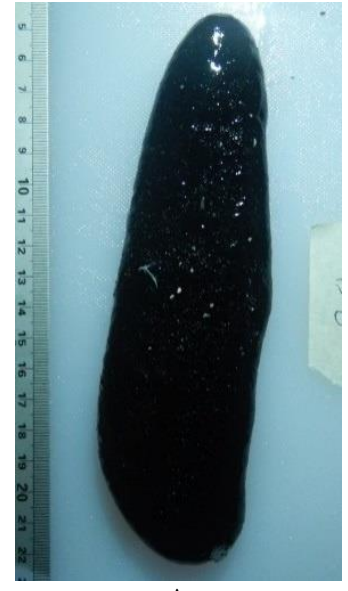

A

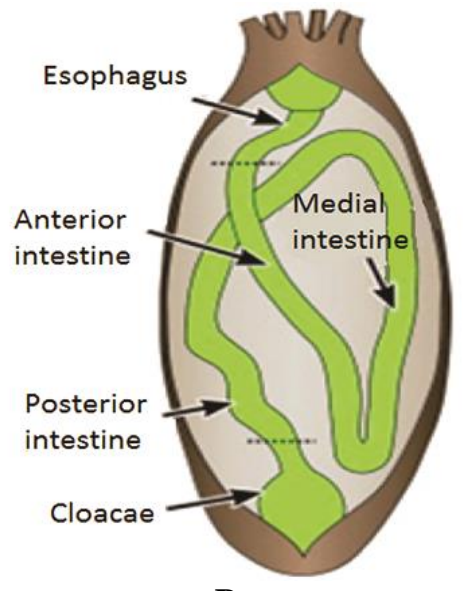

B
Figure 1. A. Selected Holothuria atra samples from Karimunjawa National Park, Indonesia. B. Position of bacterial taking in the intestine of $H$. atra (Source: Pagán-Jiménez et al. 2019)

\section{Isolation and purification of bacteria}

Isolation and purification of symbiotic bacteria were carried out at the Tropical Marine Biotechnology Laboratory, Diponegoro University. The isolation process was carried out by the serial dilution method, then the purification process is carried out by the streak plate method (Ayuningrum et al. 2019a). Before the isolation of associated bacteria, the $H$. atra specimens were dissected and the intestine pulled out under sterile condition. The intestines from each specimen were ground and serially diluted in sterile seawater, respectively. The dilution of $10^{-2}$ and $10^{-3}$ from each sample was poured on to sterile Zobell 2216E (Himedia, India) agar, incubated at $29 \pm 2^{\circ} \mathrm{C}$ for 3 days. The purification was conducted by picked up each different colony and streaked on to new fresh Zobell 2216E Media.

\section{Screening of antibacterial activity}

Screening of antibacterial activity was conducted at the Tropical Marine Biotechnology Laboratory, Diponegoro University using agar plug method (Ayuningrum et al. 2019a). Sea cucumber samples have been collected from Menjangan Besar Karimunjawa waters, and successfully filtered for their antibacterial activity against pathogenic bacteria using overlay methods (Radjasa, et al. 2013). The bacterial isolates from $H$. atra intestine were cultured for 34 days in the respected medium from optimal metabolite production. Agar blocks were taken from it and were placed on to NA medium which previously swapped with 0,5 Mc Farland $\left(10^{8} \mathrm{CFU} / \mathrm{mL}\right)$ pathogen bacteria (Escherichia coli and Bacillus cereus). Cultures then incubated at $37^{\circ} \mathrm{C}$ overnight prior to the incubation in fridge at $4^{\circ} \mathrm{C}$ for an hour. Antibacterial potential was documented and measured in millimeter $(\mathrm{mm})$ and \pm SD. 
DNA extraction and amplification of 16S r DNA

The extraction of bacterial DNA was using chelex and saponin method (Miller et al. 1999; Ayuningrum, et al. 2017). The amplification of $16 \mathrm{~S}$ rDNA was performed using universal primer $27 \mathrm{~F}$ 5' AGAGTTTGATCMTGGCTCAG-3 and $1492 \mathrm{R}$ 5'GGTTACCTTGTTACGACTT-3' (Weisburg, et al. 1991). PCR reaction with a total of $25 \mu \mathrm{L}$ was consist of $1 \mu \mathrm{L}$ DNA template, each primer of $2 \mu \mathrm{L}$, $\mathrm{ddH}_{2} \mathrm{O}$ of $10.5 \mu \mathrm{L}$ and mix PCR (MyTaq ${ }^{\mathrm{TM}}$ Red Mix-Bioline) of $12.5 \mathrm{~mL}$. Amplification reaction was conducted in a Thermal Cycler (BIO-RAD) T100 using optimization of consist of initial denaturation at $94{ }^{\circ} \mathrm{C}$ for 3 minutes, then followed by 30 cycles of denaturation at $94^{\circ} \mathrm{C}$ for 1 min each cycle, annealing at $55^{\circ} \mathrm{C}$ for 1 minute, extension at $72^{\circ} \mathrm{C}$ for 1 minute, and followed by final extension at $72^{\circ} \mathrm{C}$ for 7 minutes. The examination of PCR products was using gel electrophoresis with agarose $1 \%$, and the result was visualized by using UVIDoc HD5 (UVITEC Cambridge, UK).

\section{BLAST homology and phylogenetic tree}

The PCR products from the active bacterial isolates with desired $1500 \mathrm{bp}$ length were sent to $1^{\text {ST }}$ Base DNA Sequencing, Malaysia through the Genetika Science provider. The resulted sequence obtained were processed to create BLAST homology and Phylogenetic analysis according to Ayuningrum et al. 2019b. The analysis of sequencing result as well as alignment and phylogenetic tree was using MEGA 6 and feature neighbor-joining. The result of phylogenetic tree construction was examined using bootstrap method.

\section{RESULTS AND DISCUSSION}

\section{Environment and number of bacteria}

Both sampling location has different chemical and physical parameter value. The result of environment quality observation was displayed in Table 1.
Based on the results of the analysis of water quality at the study site, according to Minister of the Environment Decree No. 51/2004, classified as suitable, except for organic sediment material. According to Reynold (1971) that the value of suitable organic sediment material content is $3.5-7 \%$, so that the average measurement of organic sediment in the Menjangan Besar and Alang-alang waters $(2,975 \%$ and $5,309 \%)$ is relatively low to medium. As it is known that organic material is an important factor in looking at the level of eutrophication. Eutrophication is the entry of organic matter in water bodies thereby increasing excessive fertility. This is because eutrophication causes excessive changes in chemical and biological structures in the aquatic environment, including aspects of nutrients ( $\mathrm{N}$ and $\mathrm{P}$ ) and bacteria.

Organic sediment content in the Menjangan Besar waters is thought to be influenced by anthropogenic activities, namely the supply of organic waste originating from settlement activities, land tourism, marine tourism, and marine aquaculture activities at the study site, then entering the aquatic environment to the bottom. The distribution of organic waste is also influenced by currents and tides. Likewise, what happens in Alang-alang waters, even though they are included in the rehabilitation zone (non-anthropogenic), but organic waste originating from settlements and hotels on the coast can also affect the quantity of waste entering the waters, which can affect the material organic in the waters, which are further influenced by currents and tides. According to the results of the study, the results of measurements of organic material content in Menjangan Besar waters are lower than Alang-alang waters. The results of analysis of variance between organic material content in Menjangan Besar waters and Alangalang waters obtained P-value $=0.007108<0.05$ (at 95\% confidence level). This significant difference in organic material content is thought to be one of the factors that give a difference in the number of bacteria in the two study sites (Menjangan Besar as a zone that has anthropogenic effects and Alang-alang waters as a zone that has a nonanthropogenic effect).

Table 1. Aquatic and sediment quality in anthropogenic waters of Menjangan Besar and non-anthropogenic waters of Alang-alang

\begin{tabular}{|c|c|c|c|c|c|c|c|c|c|}
\hline Station & Repetition & $\begin{array}{l}\text { Visibility } \\
\quad(\mathbf{c m})\end{array}$ & $\begin{array}{c}\text { DO } \\
(\mathrm{mg} / \mathrm{L})\end{array}$ & $\begin{array}{c}\text { Depth } \\
\text { (m) }\end{array}$ & $\underset{(\circ \mathrm{C})}{\text { Temp. }}$ & $\underset{(\mathrm{m} / \mathbf{s})}{\text { Current }}$ & $\mathbf{p H}$ & $\begin{array}{l}\text { Salinity } \\
\text { (ppt) }\end{array}$ & $\begin{array}{c}\text { Organic } \\
\text { material } \\
\text { sediment }\end{array}$ \\
\hline \multirow{4}{*}{$\begin{array}{l}\text { Anthropogenic waters } \\
\text { (Menjangan Besar) }\end{array}$} & 1 & Not visible & 4.79 & 4.5 & 30.10 & 0.025 & 7.0 & 32.02 & 3.426 \\
\hline & 2 & Not visible & 4.98 & 3.9 & 29.50 & 0.046 & 6.9 & 31,54 & 2.917 \\
\hline & 3 & Not visible & 5.05 & 3.02 & 30.75 & 0.036 & 6.9 & 31,85 & 2.584 \\
\hline & Average & & 4.94 & 3.81 & 30.11 & 0.028 & 6.93 & 31.80 & 2.975 \\
\hline \multirow{4}{*}{$\begin{array}{l}\text { Non-anthropogenic } \\
\text { (Alang-alang) }\end{array}$} & 1 & Not visible & 5.95 & 2.50 & 29.51 & 0.006 & 7.7 & 32.00 & 5.426 \\
\hline & 2 & 38.03 & 5.99 & 2.90 & 30.02 & 0.006 & 7.5 & 32.01 & 5.917 \\
\hline & 2 & 70.05 & 6.12 & 2.20 & 29.89 & 0.007 & 7.8 & 31,08 & 4.584 \\
\hline & Average & & 6.02 & 2.53 & 29.80 & 0.006 & 7.6 & 31.03 & 5.309 \\
\hline
\end{tabular}




\section{Isolation and characterization of bacteria}

In the previous study, Sulardiono et al. (2019) reported that sea cucumber extract had ability to inhibit the growth of E. coli and S. aureus at concentration $150 \mathrm{mg} / \mathrm{mL}$ with the best activity. Sea cucumbers have unique adaptation strategy, one of which is that if sea cucumbers are in a depressed habitat environment, sea cucumbers will secrete bioactive compounds to defend against the attack of pathogenic bacteria in the water environment that enter its body. The role of bacteria for the sea cucumber, especially the producers of bioactive compound, remains unclear. Associated Actinobacteria could be an ecological advantage by providing the host with bioactive compounds for i.e., protection against infection by pathogenic bacteria or protection against predators (Seipke et al. 2012). Pringgenies et al. 2019 reported the finding that gut microbiome from Holothurians had ability to inhibit the growth of multidrug-resistant bacteria (Figure 2).

In this research, the total 26 of bacterial symbiont with different morphology (Table 2) isolated from five specimens of $H$. atra sea cucumber intestine. Those consist of 11 bacterial isolates from $H$. atra from the Menjangan Besar waters and 15 bacterial isolates from $H$. atra in Alang-alang waters as a rehabilitation zone. The comparison of total isolates from $H$. atra collected in different regions can be seen in Figure 3. These results indicate differences in the number of bacterial strains between the two locations. This difference is thought to be due to differences in the use of zones, where in the waters of Menjangan Besar there are more tourist and cultivation activities compared to Alang-alang waters as a rehabilitation zone. Evidently, the effect of the use of zones in the Menjangan Besar waters has an effect on the number of bacterial strains that are lower.

\section{Screening of antagonistic bacteria activity}

The production of antimicrobial substances by marine bacteria isolated from sea cucumber different locations in the sea has been known for long time (Sibero et al. 2019). This difference of total bacterial isolates from both regions might be related to the higher concentration of organic compounds in Menjangan Besar as anthropogenic area than in Alang-Alang as non-anthropogenic area. The environmental pressure affects biological activity in producing bioactive compounds as a form of adaptation. Microbial metabolites can play an important role in the chemical defense associated with the host and in forming the structure of microbiome communities. Metabolic and physiological changes experienced in extreme environmental conditions result in the production of structural and functional bioactive compounds (Rizzo and Giudice 2018). Thus, secondary metabolite was being prospected as antibacterial compounds for further antimicrobial development to human. The antibacterial test results showed the difference in the diameter of inhibition (DOI) zone from both locations (Figure 4).

Table 2. The pure isolated bacteria from Holothuria atra intestine

\begin{tabular}{|c|c|c|c|c|c|}
\hline \multirow{2}{*}{ Isolate code } & \multicolumn{5}{|c|}{ Morphological characteristics } \\
\hline & Color & Size & Shape & Margin & Elevation \\
\hline M1 & Clear white & Small & Round & lobate & Convex \\
\hline M2 & Clear white & Pin point & Round & Entire & Convex \\
\hline M3 & Turbid white & Big & Round & Entire & Convex \\
\hline M4 & White & Big & Filament & Filament & Flat \\
\hline M5 & White & Small & Round & Entire & Convex \\
\hline M6 & Yellowish white & Small & Round & Entire & Convex \\
\hline M7 & Turbid white & Big & Filament & Filament & Flat \\
\hline M8 & Clear white & Small & Round & Entire & Convex \\
\hline M9 & White & Small & Round & Entire & Convex \\
\hline M10 & Turbid white & Medium & Round & Entire & Convex \\
\hline M11 & Clear white & Big & Round & Lobate & Convex \\
\hline A1 & Yellowish white & Small & Round & Entire & raised \\
\hline $\mathrm{A} 2$ & White & Medium & Round & Entire & Convex \\
\hline A3 & Turbid white & Medium & Round & Entire & Raised \\
\hline A4 & White & Medium & Round & Entire & Raised \\
\hline A5 & Translucent white & Small & Round & Entire & Convex \\
\hline A6 & Yellow & Pint point & Round & Entire & Convex \\
\hline A7 & Yellowish white & Small & Round & Entire & Convex \\
\hline A8 & Turbid white & Big & Round & Entire & Raised \\
\hline A9 & White & Small & Round & Entire & Convex \\
\hline A10 & Turbid White & Medium & Round & Entire & Convex \\
\hline A11 & Translucent White & Big & Round & Entire & Raised \\
\hline A12 & Yellowish White & Pin point & Round & Entire & Convex \\
\hline A13 & White & Medium & Round & Entire & Convex \\
\hline A14 & Clear white & Medium & Round & Entire & Convex \\
\hline A15 & Yellowish white & Small & Irregular & Entire & Raised \\
\hline
\end{tabular}



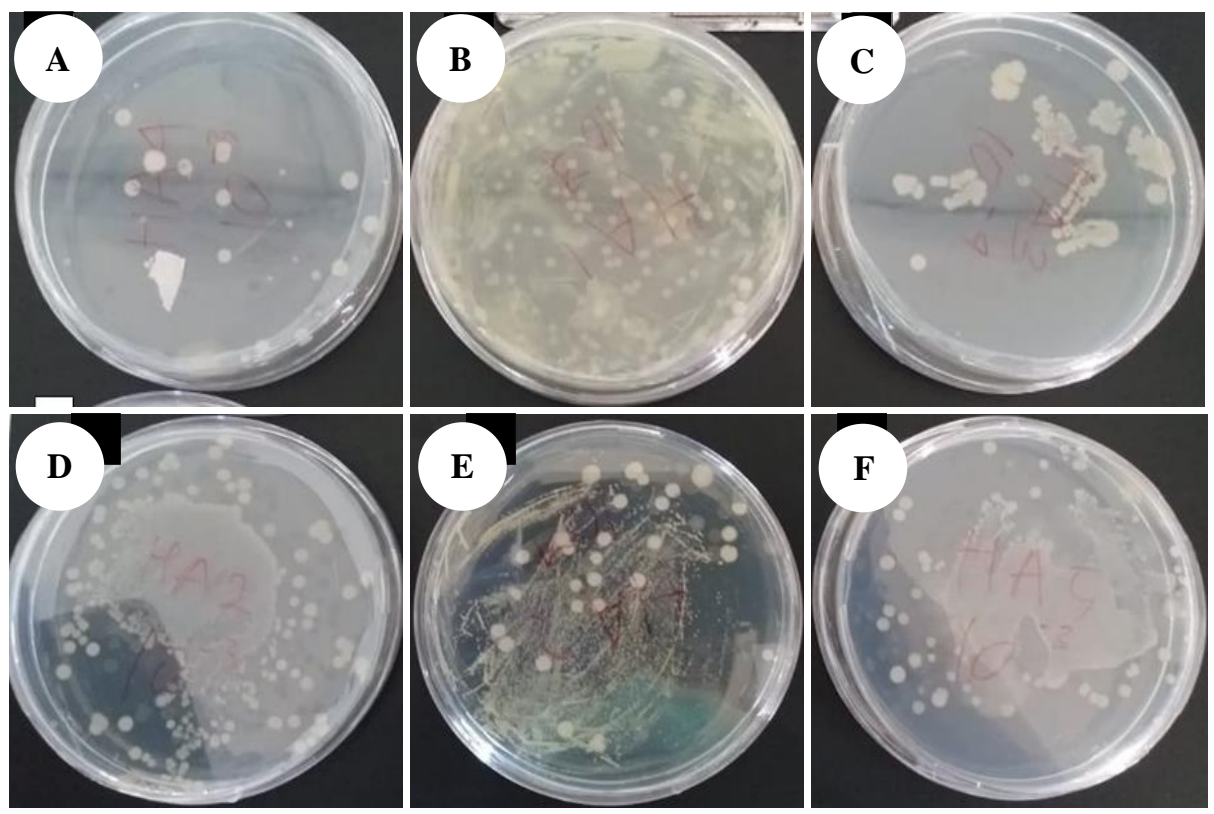

Figure 2. Some of the isolation results of the bacteria from Holothuria atra intestine. A-F refer to bacterial isolate A4, A1, A3, A2, A6 and $\mathrm{A} 5$ before purification

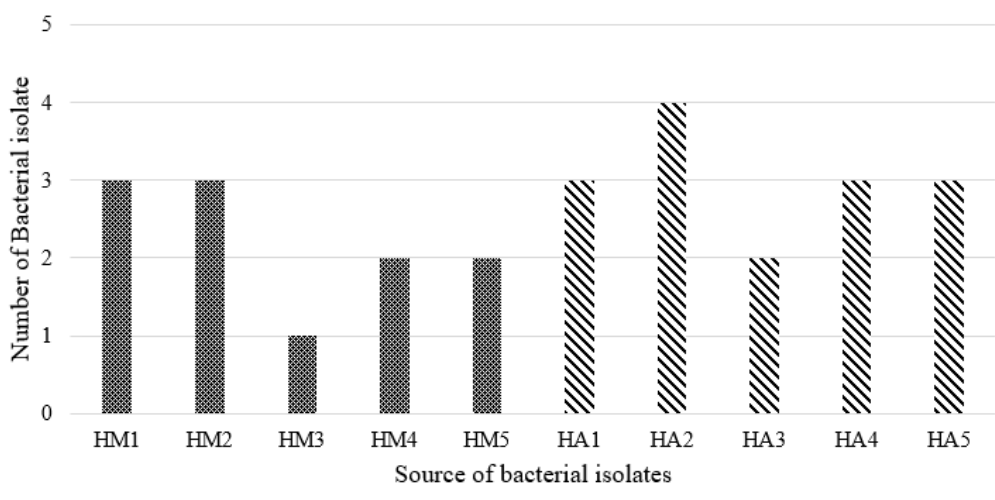

$\mathrm{HM}=$ Holothuria atra from Menjangan Besar

NN HA= Holothuria atra from Alang-alang

Figure 3. Number of Isolated Bacterial Strain from Holothuria atra collected at different regions. HM (Holothurians from Menjangan), and HA (Holothurians from Alang-alang)
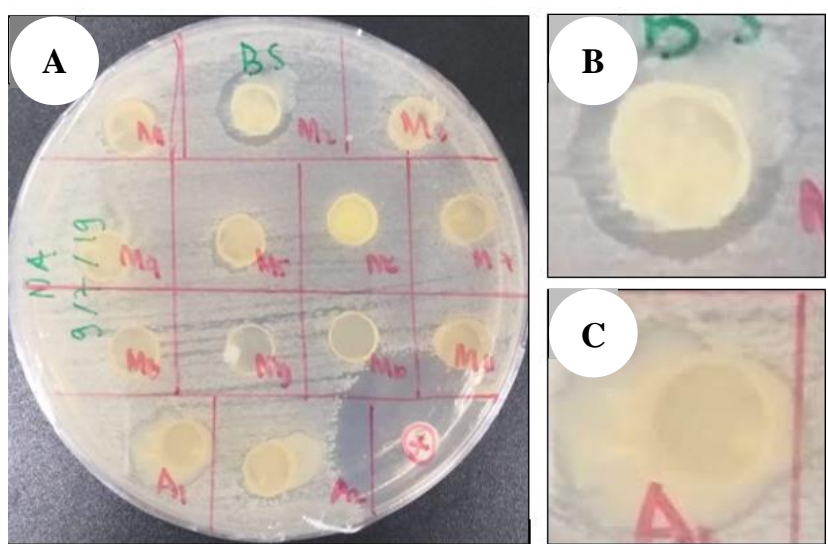

Figure 4. Screening of antagonistic activity from bacterial strain isolated from $H$. atra intestine against pathogenic bacteria. Code $\mathrm{M}$ is for bacterial isolates isolated from $\mathrm{H}$. atra in Menjangan water, meanwhile, A is for bacterial strains from $H$. atra in Alang-alang water. The zone of inhibition is from HM1.2 with diameter of inhibition (DOI) $8.2 \pm 1.5 \mathrm{~mm}$ and HA1.1. with DOI $6.3 \pm 1.5 \mathrm{~mm}$.
The ability of intestine bacteria from $H$. atra to produce antibacterial compounds indicate the presence of probiotic bacteria inside its intestine. That probiotic might be beneficial to protect the life of $H$. atra against harmful bacteria in water environment. Authors opinion that sea cucumber is benthic deposit feeder, so that the presence of waste organic material in their food might contain harmful bacteria that activate the probiotic inside its intestine. Probiotics can produce bacteriocin to fight pathogens that are selective only against some strains of pathogens (Yuniastuti 2014). The size of DOI was slightly different from both zone, indicated the different kinds of bioactive compounds or different amounts of bioactive compounds. However, this still needs further study.

\section{Amplification of partial 16S rDNA and the phylogenetic tree}

PCR-based protocols mark the ribosomal RNA gene subunit (rDNA) for study purposes in microbial taxonomy, 
phylogenetics, evolution, and ecology (dos Santos, et al. 2019). 16S rDNA was used as the marker for molecular identification bacteria. The PCR product was visualized and resulted in the band with approximately 1500 bp (Figure 5). The bacteria performed antibacterial activity (HM1.2 and HA1.1) in the prior step were successfully identified using molecular approach as Bacillus paramycoides and Vibrio alginolyticus with BLAST homology $98 \%$ and $99 \%$.

The results obtained 11 strains of bacterial isolates from Menjangan Besar waters as anthropogenic areas and 15 strains of bacterial isolates from Alang-Alang waters as non-anthropogenic areas, The antibacterial test results showed the difference in the diameter of inhibition (DOI) zone from both locations. Molecular identification showed isolates HM1.2 and HA1.1 had the closest similarity with Bacillus paramycoides and Vibrio alginolyticus with homology Blast $98 \%$ and $99 \%$.

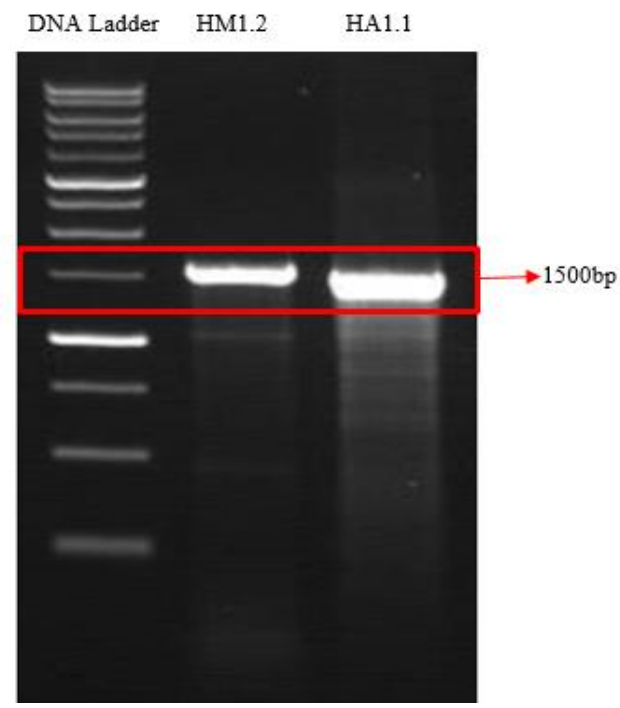

Figure 5. Visualization of electrophoresis result of bacterial strain HM1.2 and HA1.1 showing bands with a proximal length $1500 \mathrm{bp}$.

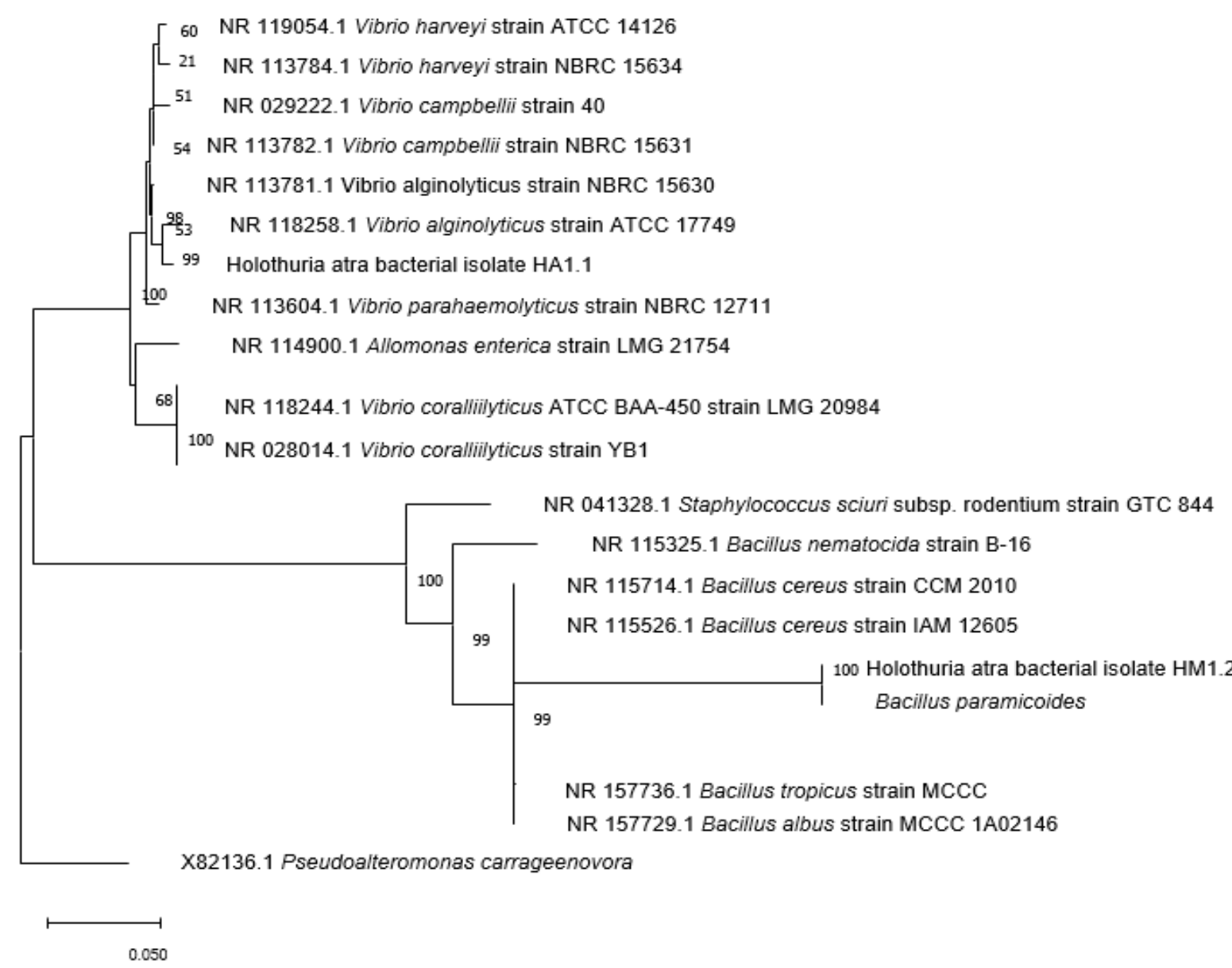

Figure 6. Phylogenetic tree of bacterial strain HM1.2 and HA1.1 
In conclusion, based on the environment quality observation, both locations have a difference in visibility and organic material sediment, with Menjangan Besar considered more turbid than Alang-alang. This turbidity is due to the stronger water current based on this study. The hypothesis of pathogenic bacteria commonly found in anthropogenic water was not proven with this approach, because in Alang-alang also found Vibrio algynolyticus inside the $H$. atra's body. V. algynolyticus is considered as pathogenic bacteria causing vibriosis in shrimp culture. Thus, to prove that hypothesis is still needed further research with another approach such as metagenomics. But, along with that, we found an interesting fact that the antibacterial properties from $H$. atra is not only from itself but also from associated bacteria living in the body, which not being reported before.

\section{ACKNOWLEDGEMENTS}

Authors thank to the Dean of the Faculty of Fisheries and Marine Sciences, Diponegoro University, Semarang, Indonesia for the opportunity given through the 2019 Faculty Grants Fund. The same goes to the leadership of the Karimunjawa National Park Office for the permission given and all research assistants and laboratory assistants, who helped a lot during the study.

\section{REFERENCES}

Ayuningrum D, Kristiana R, Nisa AA, Radjasa SK, Muchlissin SI, Radjasa OK, Sabdono A, Trianto A. 2019a. Bacteria Associated with Tunicate, Polycarpa aurata, from Lease Sea, Maluku, Indonesia exhibiting anti-multidrug resistant bacteria. Biodiversitas 20 (4): 956964. DOI: $10.13057 /$ biodiv/d200404

Ayuningrum D, Liu Y, Riyanti, Sibero MT, Kristiana R, Asagabaldan AA, Wuisan ZG, Trianto A, Radjasa OK, Sabdono A, Schaeberle TF. 2019 b. Tunicate-associated bacteria show a great potential for the discovery of antimicrobial compounds. PloS ONE 14 (3): e0213797

Baker-Austin C, Oliver JD, Alam M, Ali A, Waldor MK, Qadri F, Martinez-Urtaza J. 2018. Vibrio spp. Infections. Nat Rev Dis Primers. 4 (1): 8. DOI: 10.1038/s41572-018-0005-8.

Bordenstein SR, Theis KR. 2015. Host biology in light of the microbiome: Ten principles of holobionts and hologenomes. PLoS Biol. 13: e1002226. DOI: 10.1371/journal.pbio.1002226

Dissanayake DCT and Stefansson G. 2012. Habitat preference of sea cucumbers: Holothuria atra and Holothuria edulis in the coastal waters of Sri Lanka. J Mar Biol Assoc UK 92 (3), 581-590. DOI: 10.1017/S0025315411000051

dos Santos HRM, Argolo CS, Argôlo-Filho RC, Loguercio LL. 2019. A $16 \mathrm{~S}$ rDNA PCR-based theoretical to actual delta approach on culturable mock communities revealed severe losses of diversity information. BMC Microbiol 19: 74 DOI: 10.1186/s12866-019-14462

Hartati R, Zeinuri M, Ambariyanto, Ayodya FP, Widianingsih, Mustagpirin $M$ and Soegianto A. 2019. Initial assessment of Holothuria atra in Panjang Island, Jepara, Indonesia. Ecol Environ Conserv Paper 25: S1-S6.

Liu H, Wang L, Liu M, Wang B, Jiang K, Ma S, Li Q. 2011. The intestinal microbial diversity in Chinese shrimp (Fenneropenaeus chinensis) as determined by PCR-DGGE and clone library analyses. $\begin{array}{llll}\text { Aquaculture } & 317 & (1-4): & 32-36 .\end{array}$ 10.1016/j.aquaculture.2011.04.008

Lorenz TC. 2012. Polymerase chain reaction: basic protocol plus troubleshooting and optimization strategies. J Vis Exp 63: e3998. DOI: $10.3791 / 3998$.

McFall-Ngai M, Hadfield MG, Bosch TCG, Carey HV, Lošo TD, Douglas AE, et al. 2013. Animals in a Bacterial World, a New Imperative for the Life Sciences. Proc Natl Acad Sci USA 110 (9): 3229-3236. DOI: 10.1073/pnas.1218525110.

McTavish T, Stenton-Dozey J, Vopel K, Savage C. 2012. Deposit-feeding sea cucumber enhances mineralization and nutrient cycling in organically-enriched coastal sediments. PLoS One 7 (11): e50031 DOI: 10.1371/journal.pone.0050031

Meeks JC, Elhai J, Thiel T, Potts M, Larimer F, Lamerdin J, Predki P \& Atlas R. 2001. An overview of the genome of Nostoc punctiforme, a multicellular, symbiotic cyanobacterium,. Photosynthesis Res 70: 85106, 2001 DOI: 10.1023/A: 1013840025518

Pagán-Jiménez M, Ruiz-Calderón JF, Dominguez-Bello MG, GarcíaArrarás JE. 2019. Characterization of the intestinal microbiota of the sea cucumber Holothuria glaberrima. PLoS One 14 (1): e0208011. DOI: 10.1371/journal.pone.0208011

Pringgenies D, Yudiati E, Djunaedi A, Santosa GW, Koesoemadji. 2019. Explorations of symbiotic microbe from sea cucumber gut as an antimulti-drug resistant microbe agent for utilization in hand sanitizer products. AACL Bioflux 12 (3): 737-747.

Radjasa OK, Khoeri MM, Darusallam CC, Trimasanto H, Sudoyo H. 2013 Bacterial symbionts of reef invertebrates: screening for antipathogenic bacteria activity. Biodiversitas 14 (2): 80-86. DOI: 10.1080/14888386.2013.774937

Rizzo C and Giudice AL. 2018. Marine invertebrates: underexplored sources of bacteria producing biologically active molecules. Diversity 10 (3): 52. DOI: 10.3390/d10030052

Seipke RF, Kaltenpoth M, Hutchings MI. 2012. Streptomyces as symbionts: An emerging and widespread theme? FEMS Microbiol Rev 36: 862-876. DOI: 10.1111/j.1574-6976.2011.00313.x.

Sulardiono B, Anggoro S, Rudiyanti S, Rahman A., 2019. Assessment of the Holothuria atra (Echinodermata: Holothurians) Habitat based on the Antibacterial Effectiveness Approach at Karimunjawa, Central Java Province, Indonesia. Ocean Life 3 (1): 11-17. DOI: 10.13057/oceanlife/o30102

Sulardiono B., A'in C., Muskananfola MR. 2018. Profiles of water quality at Menjangan Besar Island, Karimunjawa, Central Java Province, Indonesia. Biodiversitas 19 (6): 2308-2315. DOI: 10.13057/biodiv/d190639

Theis KR, Dheilly NM, Klassen JL, Brucker RM, Baines JF. Bosch TCG., et al. 2016. Getting the hologenome concept right: An ecoevolutionary framework for hosts and their microbiomes. mSystems 1: e00028-16. DOI: 10.1128/mSystems.00028-16

Weisburg WG, Barns SM, Pelletier DA, Lane DJ. 1991. 16S ribosomal DNA amplification for phylogenetic study. J Bacteriol 173 (2): 697703. DOI: 10.1128/jb.173.2.697-703.1991.

Sulisyati R, Prihatinningsih P, Mulyadi. 2018. Revisi Zonasi Taman Nasional Karimunjawa sebagai Upaya Kompromi Pengelolaan Sumberdaya Alam (Zoning Review of Karimunjawa National Park as an Effort to Compromise Natural Resource Management). Proseding Seminar Nasional Geomatika 2018: Penggunaan dan Pengembangan Produk Informasi Geospasial Mendukung Daya Saing Nasional, 2018; 713-724. [Indonesian]

Reynold SC. 1971. A Manual of Introductory Soil Science and Simple Soil Analysis Methods. South Pacific Commission, Nouena, New Caledonia.

UK Standards for Microbiology Investigations. 2011. Identification of Bacillus species. Standards Unit Microbiology Services Public Health England, London.

Yuniastuti, A., 2014. Probiotik (Dalam Perspektif Kesehatan). Buku Monograf. Unnes Press, Semarang. [Indonesian] 